\title{
ERCC3 Gene Mutation
}

National Cancer Institute

\section{Source}

National Cancer Institute. ERCC3 Gene Mutation. NCI Thesaurus. Code C154227.

A change in the nucleotide sequence of the ERCC3 gene. 